\title{
Pengaruh Pendidikan Kesehatan Terhadap Sikap Dan Tindakan Pencegahan Ulkus Diabetik Pada Pasien Diabetes Mellitus Tipe 2
}

\author{
Baiq Ruli Fatmawati, Marthilda Suprayitna, Kurniati Prihatin \\ E-mail:yulithafatmawati@gmail.com
}

STIKES Yarsi Mataram

\begin{abstract}
ABSTRAK
Penyebab masalah pada kaki diabetik adalah neuropati sensori yang mengakibatkan ulkus diabetik. Komplikasi kaki diabetik menyebabkan kematian dibeberapa Negara berkembang. Ulkus kaki diabetik tidak akan terjadi bila penderita diabetes mellitus mempunyai pengetahuan dan sikap dalam menjaga serta merawat kaki secara rutin. Perawatan kaki pasien diabetes mellitus tipe II terdiri dari deteksi kelainan kaki, latihan kaki dan praktik perawatan kaki. Untuk mengetahui pengaruh pendidikan kesehatan terhadap sikap dan tindakan pencegahan ulkus diabetik pada pasien diabetes mellitus tipe 2. Rancangan penelitian quasy experiment pre test - post test with control group design, dengan sampel sebanyak 30 responden. Ada pengaruh pendidikan kesehatan terhadap sikap $(\mathrm{p}=0,000)$ dan tindakan $(\mathrm{p}=0,000)$ pencegahan ulkus kaki diabetik. Pendidikan kesehatan dapat meningkatkan perubahan sikap dan tindakan dalam pencegahan ulkus kaki diabetik pada pasien diabetes mellitus tipe II.
\end{abstract}

Kata Kunci: Pendidikan kesehatan, sikap, tindakan pencegahan ulkus diabetik, diabetes mellitus

\begin{abstract}
The most common cause of diabetic leg problems is a sensory neuropathy resulting in diabetic ulcers. Diabetes mellitus foot complications are a leading cause of mortality in developing countries. Diabetic foot ulcers can be prevented if people with diabetes mellitus have the knowledge, positive attitude and thus able to perform the diabetic foot care. Foot care of patients with diabetes mellitus type II consist of early detection, foot exercise and practice for the foot care. Objective was to determine the effect of health education on attitudes and preventive measures for diabetic foot ulcers of people with diabetes mellitus type II. This research used a design quantitative pre experimental method with control group design, with sample size of 30 respondents. The results showed that there was an effect of health education on attitudes $(p=0,000)$ and preventive actions $(p=0,000)$ of diabetic foot ulcers. Health education can improve on attitudes and preventive measures for diabetic foot ulcers of people with diabetes mellitus type II.
\end{abstract}

Keyword: health education, attitudes, prevention diabetic foot ulcers, DM patients

\section{A. LATAR BELAKANG}

Diabetes mellitus (DM) adalah suatu gangguan metabolisme karbohidrat, protein dan lemak yang ditandai oleh hiperglikemia atau peningkatan kadar glukosa dalam darah yang terjadi akibat kelainan sekresi insulin atau menurunnya kerja [1]. Hiperglikemia dapat berdampak buruk pada berbagai macam organ tubuh seperti neuropati diabetik, ulkus diabetik pada kaki, retinopati diabetik, nefropati diabetik dan gangguan pembuluh darah.

Angka kejadian DM tipe 2 mencapai 90\% hingga $95 \%$ dari seluruh penderita diabetes mellitus. World Health Organization (WHO) [2] memprediksi adanya peningkatan jumlah penyandang DM yang menjadi salah satu ancaman kesehatan global. Di Indonesia dari 8,4 juta pada tahun 2000 menjadi 21,3 juta pada 
tahun 2030 [3]. International Diabetes Federation [4] memprediksi adanya kenaikan jumlah penyandang DM di Indonesia dari 9,1 juta pada tahun 2014 menjadi 14,1 juta pada tahun 2035.

Diabetes mellitus tipe II jumlahnya lebih dari $90 \%$ dari semua populasi diabetes. Pada pasien DM tipe II lebih sulit dalam memonitor kadar gula darah karena tidak bergantung pada insulin dan lebih sering disebabkan karena gaya hidup yang tidak sehat.

Salah satu upaya preventif pada pasien DM yang sudah mengidap penyulit menahun adalah keterampilan perawatan kaki untuk mengurangi terjadinya komplikasi ulkus kaki diabetik. Penderita DM tipe II mempunyai resiko $15 \%$ terjadinya ulkus kaki diabetik pada masa hidupnya dan resiko terjadinya kekambuhan dalam 5 tahun sebesar 70\%. Sebagian besar kejadian ulkus diabetik akan berakhir dengan amputasi dan akan mengakibatkan dampak negatif terhadap kelangsungan hidup individu. Sebanyak $50 \%$ dari kasus-kasus amputasi diperkirakan dapat dicegah bila pasien diajarkan tindakan preventif untuk merawat kaki dan mempraktikannya setiap hari.

Sikap dan pencegahan dari pasien DM dalam melakukan perawatan kaki akan mengurangi resiko ulkus diabetik dan amputasi jari. Indian Health Diabetes Best Practice [5] mengatakan bahwa perawatan kaki meliputi: menjaga kebersihan kaki setiap hari, memotong kuku terutama kuku kaki dengan baik dan benar, memilih alas kaki yang baik, dan pengelolaan cedera awal pada kaki termasuk kesehatan secara umum dan gawat darurat pada kaki.

Menurut Khamseh, Vatankhah dan Baradaran [6], bahwa kurangnya pengetahuan pasien tentang perawatan kaki menjadi salah satu hambatan bagi pasien dalam melaksanakan perawatan kaki, program pendidikan kesehatan perawatan kaki sangat penting dilakukan untuk memperbaiki perilaku/sikap dalam pencegahan dan perawatan kaki pasien DM khususnya diabetes mellitus tipe II yang lebih beresiko untuk terjadinya ulkus kaki diabetik.

Ulkus kaki diabetik memberi dampak yang signifikan terhadap penurunan kualitas sumber daya manusia dan peningkatan biaya kesehatan [7]. Sulistyowati [8] memaparkan bahwa prevalensi penderita ulkus kaki diabetik sekitar $15 \%$ dengan risiko amputasi $30 \%$, angka mortalitas $32 \%$, dan di Indonesia ulkus kaki diabetik merupakan penyebab paling besar untuk dilakukan perawatan di rumah sakit sebesar $80 \%$. Upaya untuk meningkatkan pengetahuan dan sikap dalam mengubah suatu perilaku pemeliharaan kesehatan yang terusmenerus diperlukan suatu pendidikan kesehatan yang merupakan salah satu pilar pengelolaan penting bagi penderita DM [3]. Tafikurahman menjelaskan bahwa faktor emosional memperlihatkan ukuran intensitas seseorang dalam menanam perhatian terhadap suatu kegiatan atau obyek tertentu.

Pendidikan kesehatan dapat meningkatkan pengetahuan penderita DM dan merupakan program edukasi perawatan kaki yang sangat penting dilakukan untuk memperbaiki pengetahuan dan perilaku perawatan kaki pasien diabetes mellitus khususnya diabetes mellitus tipe II yang lebih beresiko untuk terjadinya ulkus kaki diabetik.

Pendidikan kesehatan dalam upaya peningkatan kesadaran penderita DM dalam melakukan perawatan kaki bukan perkara yang mudah. Hal tersebut terkait cara mengedukasi dengan berbagai karakter serta latar belakang penderita. Pendidikan kesehatan yang efektif didukung oleh penggunaan media yang menarik dan lebih mudah diterima oleh sasaran [9]. Media yang dapat dilakukan diantaranya dengan menggunakan audiovisual, leaflet dan metode demonstrasi.

Tujuan penelitian adalah menganalisis pengaruh pendidikan kesehatan terhadap sikap dan tindakan pencegahan ulkus diabetik pada pasien diabetes mellitus tipe 2 di Wilayah Kerja Puskesmas Penimbung, Kecamatan Gunungsari, Kabupaten Lombok Barat. 


\section{B. METODE PENELITIAN}

Jenis penelitian ini menggunakan quasy experiment pre test-post test with control group design. Sampel yang digunakan sebanyak 30 responden pasien DM tipe 2. Teknik pengambilan sampel menggunakan probability sampling dengan cara proportional random sampling. Data dianalisis dengan menggunakan wilcoxon signed rank test.

Kriteria Inklusi:

a. Usia 30-60 tahun

b. Mampu melakukan perawatan diri secara mandiri

c. Mampu baca tulis

d. Mampu berkomunikasi dengan baik

C. HASIL PENELITIAN

1. Hasil Univariat

Tabel 1. Data Demografi

\begin{tabular}{|c|c|c|c|c|}
\hline \multirow{2}{*}{$\begin{array}{l}\text { Karakteristik } \\
\text { Responden }\end{array}$} & \multicolumn{2}{|c|}{ Intervensi } & \multicolumn{2}{|c|}{ Kontrol } \\
\hline & $\Sigma$ & $\%$ & $\Sigma$ & $\%$ \\
\hline \multicolumn{5}{|l|}{ Umur } \\
\hline $30-39$ & 2 & 13.3 & 0 & 0 \\
\hline $40-49$ & 9 & 60.0 & 8 & 53.3 \\
\hline $50-60$ & 4 & 26.7 & 7 & 46.7 \\
\hline Total & 15 & 100 & 15 & 100 \\
\hline \multicolumn{5}{|l|}{ Jenis Kelamin } \\
\hline Laki-laki & 4 & 26.7 & 6 & 40.0 \\
\hline Perempuan & 11 & 73.3 & 9 & 60.0 \\
\hline Total & 15 & 100 & 15 & 100 \\
\hline \multicolumn{5}{|l|}{ Pendidikan } \\
\hline $\mathrm{SD}$ & 5 & 33.3 & 3 & 20.0 \\
\hline SMP & 6 & 40.0 & 8 & 53.3 \\
\hline SMA/SMK & 4 & 26.7 & 4 & 26.7 \\
\hline Total & 15 & 100 & 15 & 100 \\
\hline \multicolumn{5}{|c|}{ LamaMenderita DM } \\
\hline$<5$ tahun & 3 & 20.0 & 5 & 33.3 \\
\hline $5-10$ tahun & 8 & 53.3 & 7 & 46.7 \\
\hline$>10$ tahun & 4 & 26.7 & 3 & 20.0 \\
\hline Total & 15 & 100 & 15 & 100 \\
\hline
\end{tabular}

Sebagian besar responden pada kelompok intervensi adalah berusia rata-rata 40-49 tahun sebanyak 9 orang (60\%), dengan jenis kelamin perempuan sebanyak 11 orang (73.3\%), pendidikan responden sebagian besar lulusan SMP sebanyak 6 orang (40\%), dan lama menderita DM sebagian besar 5-10 tahun sebanyak 8 orang $(26.7 \%)$.

Pada kelompok kontrol, responden tara-rata rata-rata 40-49 tahun sebanyak 8 orang (53.3\%), dengan jenis kelamin perempuan sebanyak 9 orang $(60 \%)$, pendidikan responden sebagian besar lulusan SMP sebanyak 8 orang (53.3\%), dan lama menderita DM sebagian besar 5-10 tahun sebanyak 7 orang (46.7\%).

\section{Hasil bivariat}

a. Sikap pencegahan ulkus kaki diabetik pada kelompok perlakuan dan kelompok kontrol sebelum dan setelah diberikan pendidikan kesehatan

Tabel 2. Distribusi frekuensi nilai sikap responden penderita DM pada kelompok perlakuan dan kelompok kontrol sebelum dan setelah diberikan pendidikan kesehatan

\begin{tabular}{|c|c|c|c|c|c|c|c|c|}
\hline \multirow[t]{3}{*}{ Sikap } & \multicolumn{4}{|c|}{$\begin{array}{c}\text { Kelompok Perlakuan } \\
\qquad(\mathbf{n}=15)\end{array}$} & \multicolumn{4}{|c|}{$\begin{array}{c}\text { Kelompok } \\
\text { Kontrol } \\
(\mathbf{n}=15)\end{array}$} \\
\hline & \multicolumn{2}{|c|}{ Pre } & \multicolumn{2}{|c|}{ Post } & \multicolumn{2}{|c|}{ Pre } & \multicolumn{2}{|c|}{ Post } \\
\hline & $\Sigma$ & $\%$ & $\Sigma$ & $\%$ & & $\%$ & $\Sigma$ & $\%$ \\
\hline Positif & 0 & 0 & 0 & 0 & 0 & 0 & 0 & 0 \\
\hline Cukup Positif & 2 & 13.3 & 11 & 73,3 & 5 & 33,3 & 3 & 20 \\
\hline Negatif & 13 & 86,7 & 4 & 26,7 & 10 & 66,7 & 12 & 80 \\
\hline $\begin{array}{l}\text { wilcoxon signed } \\
\text { rank test }\end{array}$ & & & 0,00 & & & $\rho=0,0$ & & \\
\hline
\end{tabular}

Hasil pengukuran nilai sikap responden tentang pencegahan ulkus kaki diabetik sebelum diberikan pendidikan kesehatan menunjukkan bahwa sebagian besar responden yang berada dalam kelompok perlakuan memiliki sikap yang negatif yaitu sebanyak 13 orang $(86,7 \%)$. Sedangkan pada kelompok kontrol memiliki sikap yang negatif tentang pencegahan ulkus kaki diabetik yaitu sebanyak 10 orang $(66,7 \%)$.

Setelah diberikan pendidikan kesehatan sebagian besar responden yang berada dalam kelompok perlakuan memiliki sikap yang cukup positif yaitu sebanyak 11 orang $(73,3 \%)$. Sedangkan pada kelompok kontrol memiliki sikap yang cukup positif tentang pencegahan ulkus kaki diabetik yaitu sebanyak 3 orang (20\%).

Hasil analisis perbedaan nilai sikap sebelum dan setelah pendidikan kesehatan pada kelompok perlakuan diperoleh nilai $\mathrm{p}<0,05$ yang berarti terdapat perbedaan signifikan tentang sikap pencegahan ulkus kaki diabetik 
pada kelompok perlakuan sebelum dan setelah diberikan pendidikan kesehatan. Sedangkan pada kelompok kontrol diperoleh nilai $\rho>0,05$, tidak terdapat perbedaan signifikan terhadap nilai sikap pencegahan ulkus kaki diabetik sebelum dan setelah diberikan pendidikan kesehatan.

b. Tindakan pencegahan ulkus kaki diabetik pada kelompok perlakuan dan kelompok kontrol sebelum dan setelah setelah diberikan pendidikan kesehatan

Tabel 3. Distribusi frekuensi tindakan responden penderita DM pada kelompok perlakuan dan

kelompok kontrol sebelum dan setelah diberikan pendidikan kesehatan

\begin{tabular}{|c|c|c|c|c|c|c|c|c|}
\hline \multirow[t]{3}{*}{ Tindakan } & \multicolumn{4}{|c|}{$\begin{array}{l}\text { Kelompok Perlakuan } \\
\qquad(\mathrm{n}=15)\end{array}$} & \multicolumn{4}{|c|}{$\begin{array}{c}\text { Kelompok } \\
\text { Kontrol } \\
(\mathbf{n}=\mathbf{1 5})\end{array}$} \\
\hline & \multicolumn{2}{|c|}{ Pre } & \multicolumn{2}{|c|}{ Post } & \multicolumn{2}{|c|}{ Pre } & \multicolumn{2}{|c|}{ Post } \\
\hline & $\Sigma$ & $\%$ & $\Sigma$ & $\%$ & & $\%$ & $\Sigma$ & $\%$ \\
\hline Baik & 0 & 0 & 0 & 0 & 0 & 0 & 0 & 0 \\
\hline Cukup & 0 & 0 & 12 & 80 & 0 & 0 & 0 & 0 \\
\hline Kurang & 15 & 100 & 3 & 20 & 15 & 100 & 15 & 100 \\
\hline $\begin{array}{l}\text { wilcoxon } \\
\text { signed rank } \\
\text { test }\end{array}$ & & \multicolumn{3}{|c|}{$\rho=0,00$} & \multicolumn{3}{|c|}{$\rho=0,05$} & \\
\hline
\end{tabular}

Hasil pengukuran nilai tindakan responden tentang pencegahan ulkus kaki diabetik sebelum diberikan menunjukkan bahwa sebagian besar responden yang berada dalam kelompok perlakuan memiliki tindakan yang kurang yaitu sebanyak 15 orang (100\%). Jumlah tersebut sama dengan kelompok kontrol dimana responden yang memiliki tindakan yang kurang tentang pencegahan ulkus kaki diabetik yaitu sebanyak 15 orang (100\%). Setelah diberikan pendidikan kesehatan menunjukkan bahwa sebagian besar responden yang berada dalam kelompok perlakuan memiliki tindakan yang cukup yaitu sebanyak 12 orang (80\%). Jumlah tersebut lebih banyak dibandingkan pada kelompok kontrol dimana responden yang memiliki tindakan yang cukup tentang pencegahan ulkus kaki diabetik yaitu sebanyak 0 orang $(0 \%)$.

Hasil analisis perbedaan tindakan sebelum dan setelah pendidikan kesehatan pada kelompok perlakuan diperoleh nilai $\mathrm{p}<0,05$ yaitu terdapat perbedaan signifikan nilai tindakan pencegahan ulkus kaki diabetik pada kelompok perlakuan sebelum dan setelah diberikan pendidikan kesehatan. Sedangkan pada kelompok kontrol diperoleh nilai $\rho>0,05$ berarti tidak terdapat perbedaan signifikan nilai tindakan pencegahan ulkus kaki diabetik sebelum dan setelah diberikan pendidikan kesehatan.

c. Pengaruh pendidikan kesehatan terhadap sikap dan tindakan pencegahan ulkus kaki diabetik

Tabel 4. Hasil uji perbandingan sikap dan tindakan responden penderita DM pada

kelompok perlakuan dan kelompok kontrol setelah diberikan pendidikan kesehatan.

\begin{tabular}{lc}
\hline \multicolumn{1}{c}{ Variabel } & Mean \pm SD \\
\hline Sikap & \\
\hline a. Kelompok Perlakuan & $68,7 \pm 6,19$ \\
b. Kelompok Kontrol & $55,8 \pm 4,77$ \\
\hline Mann Whitney UTest & $\rho=0,00$ \\
\hline Tindakan & \\
\hline a. Kelompok & $63,4 \pm 7,64$ \\
$\quad$ Perlakuan & \\
b. Kelompok Kontrol & $36,2 \pm 9,10$ \\
\hline Mann Whitney UTest & $\rho=0,00$ \\
\hline
\end{tabular}

Setelah diberikan pendidikan kesehatan, rerata nilai sikap pada kelompok perlakuan yaitu 68.7 lebih tinggi dibandingkan dengan nilai rerata kelompok kontrol yaitu 55,8. Rerata nilai tindakan setelah diberikan pendidikan kesehatan pada kelompok perlakuan yaitu 63,4 lebih tinggi dibandingkan dengan nilai rerata kelompok kontrol yaitu 36,2. Dengan nilai $\rho=$ $0,000(\mathrm{p}<0,05)$ yang berarti terdapat perbedaan yang signifikan antara sikap dan tindakan setelah diberikan pendidikan kesehatan pada kelompok perlakuan. Hal ini menunjukkan bahwa pemberian pendidikan kesehatan pada penderita DM berpengaruh signifikan terhadap peningkatan sikap dan tindakan dalam pencegahan ulkus kaki diabetik.

\section{PEMBAHASAN}

Karaktersistik responden berdasarkan umur sebagian besar berusia 40-49 tahun baik pada 
kelompok intervensi dan kelompok kontrol. Menurut Soegondo [10] bahwa DM tipe II biasanya terjadi setelah usia diatas 30 tahun dan semakin sering terjadi setelah usia 40 tahun serta akan terus meningkat pada usia lanjut. WHO menyebutkan bahwa setelah usia 30 tahun, kadar glukosa darah akan meningkat 1-2 $\mathrm{mg} / \mathrm{dl} /$ tahun pada saat puasa dan naik 5,6-13 $\mathrm{mg} / \mathrm{dl} /$ tahun pada 2 jam setelah makan [11].

Karakteristik responden berdasarkan jenis kelamin pada kelompok intervensi sebanyak 11 orang dan kelompok kontrol sebanyak 9 orang berjenis kelamin perempuan. Hasil penelitian ini sejalan dengan penelitian yang dilakukan oleh Santoso, Lian dan Yudi bahwa perempuan lebih banyak menderita DM dibandingkan dengan laki-laki dikarenakan adanya persentase timbunan lemak badan yang lebih besar sehingga dapat menurunkan sensitifitas terhadap kerja insulin.

Karakteristik responden berdasarkan tingkat pendidikan, pada kelompok intervensi dan kontrol sebagian besar berpendidikan SMP. Tingkat pendidikan dapat mempengaruhi kemampuan seseorang dalam melakukan perubahan perilaku kesehatan [12]. Orang yang berpendidikan lebih tinggi punya kesempatan yang luas untuk terpapar berbagai informasi. Menurut Yusra [13], bahwa tingkat pendidikan mempengaruhi perilaku seseorang dalam mencari perawatan dan pengobatan penyakit yang dideritanya, serta memilih dan memutuskan tindakan atau terapi yang akan dijalani untuk mengatasi masalah kesehatannya. Noordiani, Waluyo \& Sukmarini [14] menambahkan bahwa pengetahuan tentang perawatan kaki yang tepat secara positif dipengaruhi oleh pendidikan klien sehingga dapat mengurangi resiko terjadinya komplikasi pada kaki.

Karakteristik responden berdasarkan lama menderita diabetes mellitus sebagian besar baik kelompok intervensi maupun kontrol rata-rata 5-10 tahun. Lamanya pasien menderita diabetes mellitus dikaitkan dengan komplikasi kronik yang menyertainya. Semakin lama pasien menderita diabetes mellitus dengan kondisi Hiperglikemia, maka semakin tinggi kemungkinan terjadinya komplikasi kronik karena adanya kadar glukosa darah yang abnormal [15].

Sikap penderita DM sebelum diberikan pendidikan kesehatan antara kelompok intervensi dan kontrol adalah sama. Menurut [16], Salah satu faktor-faktor yang mempengaruhi sikap keluarga terhadap obyek sikap adalah, pengalaman pribadi, untuk dapat menjadi dasar pembentukan sikap, pengalaman pribadi haruslah meninggalkan kesan yang kuat. Sikap akan lebih mudah terbentuk apabila pengalaman pribadi tersebut terjadi dalam situasi yang melibatkan faktor emosional. Setelah didilakukan intervensi sikap kelompok kontrol sesudah diberikan pendidikan kesehatan sesuai program dari puskesmas, tidak menunjukkan adanya perubahan yang signifikan, sikap penderita DM sebagian besar masih negatif. Sebaliknya dengan kelompok intevensi setelah diberikan pendidikan kesehatan menunjukkan adanya perubahan yang signifikan. Sikap dapat dirubah apabila menggunakan kombinasi dari berbagai metode yaitu diskusi kelompok, tanya jawab, roleplay, film/video, tape recorder dan juga dengan menggunakan simulasi. Metode ceramah yang cenderung monoton dan membosankan mengakibatkan responden tidak fokus dan terpusat pada edukasi yang diberikan sehingga tidak dapat merubah ketertarikan responden untuk mendengarkan informasi yang diberikan dan sangat mempengaruhi untuk terjadinya perubahan sikap tersebut.

Tindakan pencegahan dan perawatan kaki sebelum diberikan intervensi masih dalam kategori kurang, baik pada kelompok kontrol maupun perlakuan. Menurut Yusra [13], bahwa tingkat pendidikan mempengaruhi perilaku seseorang dalam mencari perawatan dan pengobatan penyakit yang dideritanya, serta memilih dan memutuskan tindakan atau terapi yang akan dijalani untuk mengatasi masalah kesehatannya. Selain itu jika dilihat dari data 
keaktifan penderita DM dalam mengikuti pendidikan kesehatan yang dilaksanakan oleh pihak puskesmas menjadi salah satu faktor penyebab. Hasil penelitian sebelumnya melaporkan bahwa keterlibatan aktif dari responden menghasilkan perilaku perawatan kaki yang lebih baik [17].

Dengan memberikan informasi atau penyuluhan dan sebagainya akan meningkatkan perubahan sikap dari responden tentang hal tersebut dan menimbulkan kesadaran yang menyebabkan orang berperilaku sesuai dengan pengetahuan yang dimilikinya. Hasil penelitian dari Khamseh, Vatankhah dan Baradaran [6]; Desalu, Salawu, Jimoh, Adekoya, Busari dan Olokoba [18], kurangnya pengetahuan pasien tentang perawatan kaki menjadi salah satu hambatan bagi pasien dalam melaksanakan perawatan kaki. Tindakan yang didasari oleh pengetahuan akan lebih langgeng daripada tindakan yang tidak disadari pengetahuan.

Perubahan sikap kelompok perlakuan sesudah diberikan pendidikan kesehatan menggunakan metode ceramah dan demonstrasi dengan media audiovisual dan leaflet diketahui adanya perbedaan yang signifikan antara sebelum dan sesudah diberikan pendidikan kesehatan perawatan kaki. Hal ini sejalan dengan penelitian yang dilakukan Beiranvand, Fayazi, Asadizake [19] yang menunjukkan peningkatan yang signifikan nilai rata-rata pengetahuan, sikap, dan praktik perawatan kaki dari kelompok perlakuan dibandingkan dengan kelompok kontrol setelah diberikan pendidikan kesehatan.

Dalam menentukan sikap yang utuh, pengetahuan, pikiran, keyakinan dan emosi memegang peranan penting. Sikap mempunyai tiga komponen pokok yaitu kepercayaan atau keyakinan, ide dan konsep terhadap suatu objek, kehidupan emosional atau evaluasi terhadap suatu objek; dan kecenderungan untuk bertindak. Sikap penderita DM terhadap pencegahan ulkus kaki diabetik sangat dipengaruhi oleh pemahaman tentang tata cara perawatan kaki diabetik yang dapat diperoleh melalui pendidikan kesehatan.

Tindakan pencegahan dan perawatan kaki oleh kelompok perlakuan sesudah diberikan edukasi kesehatan menggunakan metode ceramah dan demonstrasi serta media audivisual dan leaflet diketahui adanya perbedaan yang signifikan antara sebelum dan sesudah diberikan edukasi kesehatan perawatan kaki. Menurut PERKENI [3], penatalaksanaan DM adalah pemberian pendidikan kesehatan. Edukasi memegang peranan penting dalam penatalaksanaan DM tipe 2 karena pemberian edukasi kepada penderita dapat merubah perilaku pasien dalam melakukan pengelolaan DM secara mandiri yang berkenaan dengan perawatan kaki secara berkala.

Pendidikan kesehatan merupakan upaya persuasi atau pembelajaran kepada masyarakat agar masyarakat mau melakukan tindakan untuk memelihara, dan meningkatkan taraf kesehatannya [12]. Penelitian yang dilakukan oleh Vatankhah, Khamseh, Noudeh, Aghili, Baradaran, \& Haeri [20] menunjukkan pemberian pendidikan kesehatan perawatan kaki dapat memperbaiki perilaku perawatan kaki. Hasil penelitian lainnya dengan metode yang sama juga dilakukan oleh Beiranvand, Fayazi, dan Asadizake [19].

Keberhasilan pendidikan kesehatan dalam merubah tindakan penderita DM dalam perawatan kaki diabetik dipengaruhi metode penyampaian pesan. Metode demonstrasi dinilai sangat efektif dalam merubah perilaku kesehatan. Metode demonstrasi tingkat pemahaman akan mencapai 90\% [21]

\section{E. KESIMPULAN}

Berdasarkan hasil penelitian yang telah dilakukan tentang pengaruh pendidikan kesehatan terhadap sikap dan tindakan pencegahan ulkus diabetik pada pasien diabetes mellitus tipe 2 di Wilayah Kerja Puskesmas Penimbung, Kecamatan Gunungsari, Kabupaten Lombok Barat. dapat disimpulkan sebagai berikut : 
Pendidikan kesehatan perawatan kaki efektif dalam merubah sikap. Setelah mendapatkan pendidikan kesehatan tentang perawatan kaki, sebagian besar sikap responden berada pada kategori cukup positif.

Pendidikan kesehatan perawatan kaki efektif dalam mengubah tindakan pencegahan ulkus kaki diabetik. Setelah mendapatkan pendidikan kesehatan tentang perawatan kaki, sebagian besar tindakan responden berada pada kategori cukup

Pendidikan kesehatan perawatan kaki berpengaruh terhadap sikap dan tindakan pencegahan ulkus kaki diabetik.

Hasil penelitian ini diharapkan agar tenaga kesehatan dapat menjalankan peran sebagai edukator untuk memberikan pendidikan kesehatan terutama pada pasien diabetes mellitus tipe 2 mengenai perawatan kaki untuk mencegah ulkus diabetik. Keluarga diharapkan dapat memberikan dukungan kepada pasien agar mengembangkan dan mempertahankan perilaku kesehatan yang positif terutama dalam melakukan tindakan perawatan kaki untuk mencegah ulkus diabetik.

\section{DAFTAR PUSTAKA}

[1] American Diabetes Assosiation. (2016). Journal Standarts of Medical Care in Diabetes. USA: The American Association of Diabetes Educators, the American Diabetes Association

[2] World Health Organization (WHO). (2000). Penatalaksanaan diabetes militus di Indonesia. EGC: Jakarta.

[3] Perkumpulan Endokrin Indonesia (Perkeni). (2015). Konsensus Pengelolaan dan Pencegahan Diabetes Melitus Tipe 2 di Indonesia.

[4] International Diabetes Federation (IDF). (2014). International Diabetes Atlas. International Diabetes Federation

[5] Indian Health Best Practices. (2011). Foot Care. Indian Health Services Division of Diabetes Treatment and Prevention Available.

[6] Khamseh, ME, Vatankhah, N, Baradaran, HR (2007), " Knowledge and practice of foot care in iranian people with type 2 diabetes" International Wound Journal, 4: 4

[7] Rahmawati, Tahlil T, Syahrul. (2016). Pengaruh Program Diabetes Self Management Education Terhadap Manajemen Diri Pada Penderita Diabetes Mellitus Tipe 2. Jurnal Ilmu Keperawatan. Vol 4 No.1, Hal 46-58

[8] Sulistyowati, DA (2015). Efektivitas Elevasi Ektrimitas Bawah Terhadap Proses Penyembuhan Ulkus Diabetik di Ruang Melati RSUD Dr. Moewardi Tahun 2014"e, Kosala, Vol: 3, No:1, Hal: 83-88

[9] Dari, NW, Nurchayati, S dan Hasanah, O (2014). Pengaruh pendidikan kesehatan senam kaki melalui media audiovisual terhadap pengetahuan pelaksanaan senam kaki pada pasien DM tipe 2 .

[10] Soegondo,S., Soewondo, P \& Subekti, I. (2015). Penatalaksanaan Diabetes Mellitus Terpadu. Edisi 2. Cetakan ke-10, Balai Penerbit FKUI: Jakarta

[11] Smeltzer, Suzanne,C., dan Brenda GB. (2013). Buku Ajar Keperawatan Medikal Bedah 2 edisi 8. Buku Kedokteran EGC: Jakarta

[12] Notoatmodjo, S. (2010). Ilmu Perilaku Kesehatan. Rineka Cipta: Jakarta

[13] Yusra, A. (2011). Hubungan antara dukungan keluarga dan kualitas hidup pasien DM tipe 2 di Poliklink Penyakit Dalam Rumah Sakit Umum Pusat Fatmawati Jakarta.

[14] Noordiani, Waluyo A, Sukmarinil L. (2013). Pengetahuan klien tentang diabetes mellitus Tipe 2 berpengaruh terhadap kemampuan klien merawat kaki. Jurnal Keperawatan Indonesia, Vol 16 No. 02

[15] Waspadji, S. (2009). Buku Ajar Penyakit Dalam: Kaki Diabetes. Jilid III.Edisi4, Jakarta.

[16] Purwanto, H .(1998). Pengantar perilaku manusia. EGC: Jakarta

[17] Sae-Sia, W., Maneewat, K., \& Kurniawan, T. (2013). Effect of a self-management support program on diabetic foot care behaviors. International Journal of Research in Nursing, (1), 14.

[18] Desalu, FK Salawu, AK Jimoh, AO Adekoya, OA Busari, AB Olokoba. (2011). Diabetic foot care: Self reported knowledge and practice among patients 
attending three tertiary hospital in Nigeria. Ghana Medical Journal, Vol.4 No.2

[19] Beiranvand S, Fayazi S, dan Asadizake M. (2015). Effect of educational programs on the knowledge, attitude, and practice of foot care in patients with diabetes. Jundishapur J chronic dis care 4(2)

[20] Vatankhah, N., Khamseh, M.E., Noudeh, Y.J., Aghili, R., Baradaran, H.R., \& Haeri, N.S. (2009). The effectiveness of foot care education on people with type 2 diabetes in Tehran, Iran. Primary Care Diabetes, 3, $73-77$.

[21] Silaban, R .(2012). Pengaruh Penggunaaan Macromedia Lash, Prigram Power point dan Peta Konsep terhadap Hasil Belajar Kimia pada Pokok Bahasan Hidrokarbon. Medan: Perpustakaan Universitas Negeri Medan 